\title{
Quality of indoor residential air and health
}

\author{
Robert Dales MD MSc(Epid), Ling Liu MMD PhD, Amanda J. Wheeler PhD, Nicolas L. Gilbert MSc
}

\section{ABSTRACT}

About $90 \%$ of our time is spent indoors where we are exposed to chemical and biological contaminants and possibly to carcinogens. These agents may influence the risk of developing nonspecific respiratory and neurologic symptoms, allergies, asthma and lung cancer. We review the sources, health effects and control strategies for several of these agents. There are conflicting data about indoor allergens. Early exposure may increase or may decrease the risk of future sensitization. Reports of indoor moulds or dampness or both are consistently associated with increased respiratory symptoms but causality has not been established. After cigarette smoking, exposure to environmental tobacco smoke and radon are the most common causes of lung cancer. Homeowners can improve the air quality in their homes, often with relatively simple measures, which should provide health benefits.

Une version française de ce résumé est disponible à l'adresse www.cmaj.ca/cgi/content/full/179/2/147/DC1

CMAJ 2008;179(2)147-52

I $\mathrm{n}$ North America, adults spend about $87 \%$ of their time in buildings, $6 \%$ in vehicles and $7 \%$ outdoors. ${ }^{1}$ Leech and colleagues ${ }^{2}$ have reported that Canadians spend similar amounts of time indoors. Typically, more time is spent indoors in very hot or cold climates. As a result, personal exposure to airborne substances is more closely related to indoor rather than outdoor pollution. ${ }^{3,4} \mathrm{We}$ review the sources, health effects and control strategies for several of the most important sources of residential biological and chemical contaminants.

Although outdoor and indoor environments tend to be viewed as distinct entities, some outdoor pollutants enter the home. However, less air pollution enters tightly sealed homes, such as those found in colder and hotter climates where windows and doors are more regularly closed to retain conditioned air. ${ }^{5}$ In addition, economically disadvantaged families may be more likely than others to live close to roadways and industry, have lower-quality housing and have less access to air conditioning, which may result in poor indoor air quality. On days with high concentrations of particulate matter, cities with a high prevalence of air conditioner use report fewer hospital admissions for cardiovascular disease, chronic obstructive pulmonary disease and pneumonia compared with cities with lower air conditioner use. ${ }^{5}$
Indoor air pollutants include carcinogens and biological and chemical contaminants. The latter category can be divided into combustion products and gases released from indoor materials (off-gassing emissions). Several guidelines for exposure limits for indoor air contaminents have been developed by the Canadian government (Table 1). Overall, indoor air contaminants have largely been shown to exacerbate pre-existing conditions; however, few studies have examined causality.

\section{Biological contaminants}

\section{Allergens}

The most common indoor sources of allergens are furry pets and dust mites. Dust mite allergens can worsen pre-existing asthma. ${ }^{10}$ Cats and cockroaches can exacerbate pre-existing asthma, and dogs and indoor fungal contamination are associated with worsening asthma. ${ }^{10}$

However, immune tolerance has been reported, especially with high allergen exposure. ${ }^{11}$ Dust mite allergens have been reported to increase the risk of developing asthma. ${ }^{10}$ Early exposure to cats or dogs has been reported to both increase and decrease the risk of allergy. ${ }^{12}$ One cohort study that included 1300 newborns followed for up to 7 years reported no significant association between mite and cat allergens in floor dust and the development of asthma..$^{13}$ These conflicting observations make it difficult to provide clear recommendations about whether to remove pets from the home to prevent the development of allergic disease in children who have not already been sensitized.

\section{Endotoxins}

Endotoxins are lipopolysaccharide components of the outer membranes of gram-negative bacteria. Increased endotoxins or gram-negative bacteria are associated with contaminated humidifiers, lower ventilation rates, presence of cats and dogs, storage of food waste and increased amounts of settled dust. ${ }^{14,15}$ Increased levels of endotoxins in house dust have been associated with increases in asthma symptoms and use of asthma medications and with reduced lung function in people with atopy or asthma. ${ }^{16,17}$ Among Canadian children

From the University of Ottawa (Dales), the Air Quality Health Effects Research Section, Biostatistics and Epidemiology Division (Dales, Liu); the Environmental Health Sciences Bureau (Liu), and the Air Health Effects Division, Water, Air and Climate Change Bureau (Wheeler, Gilbert), Health Canada, Ottawa, Ont. 
Table 1: Health Canada recommendations for indoor air quality

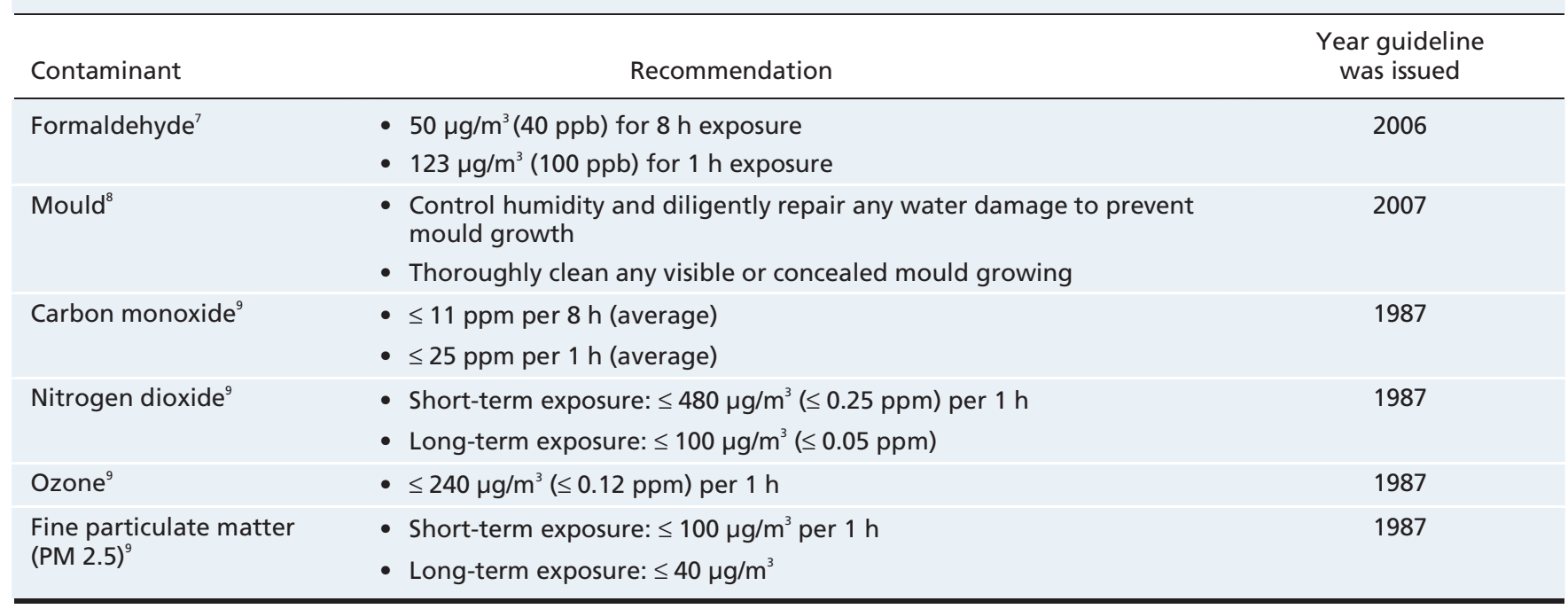

Note: $p p b=$ parts per billion, ppm = parts per million.

followed from birth to 2 years, a doubling of the indoor air endotoxin concentration was associated with an increase of 0.32 episodes of illness each year $(p=0.0003) .{ }^{18}$

Despite these adverse effects, early exposure to endotoxins may reduce future allergies and asthma. ${ }^{19}$ Endotoxins induce production of interleukin-12 and interferon- $\gamma$, which may decrease expression of Th2 lymphocytes that help mediate atopy and asthma. ${ }^{20}$ Consistent with this is the observation that children who grow up on farms, where endotoxin exposure is higher than in urban areas, have lower rates of atopy..$^{19,21}$

\section{Building-related dampness and mould}

Apart from floods, there are 4 major sources of mould growth in residences: leaks in building fabric, condensation, unattended plumbing leaks and household mould (e.g., mould growth on kitchen and bathroom surfaces, hidden food spills, garbages, defrost pans). ${ }^{22}$ A large number of cross-sectional and case-control studies from several countries have found an association between mould or dampness in the home and health complaints. ${ }^{8}$ A recent meta-analysis of the health effects associated with dampness and mould reported pooled odds ratios $(\mathrm{OR})$ of 1.70 (95\% confidence interval [CI] 1.44-2.00) for upper respiratory symptoms, 1.67 (95\% CI 1.49-1.86) for cough, 1.50 (95\% CI 1.38-1.64) for wheeze and $1.56\left(95 \%\right.$ CI 1.30-1.86) for current asthma. ${ }^{23}$

If home dampness or mould is causal, it could account for $30 \%-50 \%$ of respiratory symptoms. Most studies have not objectively measured mould growth or health outcomes. Home dampness may be a proxy for mould growth; however, dampness may also be a marker for dust mites, endotoxins and reduced ventilation, which could increase concentrations of indoor pollutants. A causal relation is biologically plausible given that indoor fungi produce allergens, irritants and toxins. The US Institute of Medicine's Committee on Damp Indoor Spaces and Health concluded that there was sufficient evidence of an association between dampness and health outcomes; however, causality had not been established. ${ }^{24}$

\section{Chemical contaminants}

\section{Combustion products}

\section{Environmental tobacco smoke}

The 2006 US Surgeon General's report is one of the most recent comprehensive reviews of the adverse health effects of environmental tobacco smoke. ${ }^{25}$ This report states that environmental tobacco smoke is a cause of premature mortality. Living with a smoker is associated with an estimated 20\%-30\% increased risk of lung cancer. Environmental tobacco smoke is also associated with a $25 \%-35 \%$ increased risk of coronary artery disease. Among children, environmental tobacco smoke has been reported to increase the risk of childhood cough and wheeze, admission to hospital for respiratory illness and sudden infant death syndrome. Environmental tobacco smoke also slows lung growth. ${ }^{25}$

\section{Coal and biomass fuels}

Coal, wood and plant residues are commonly used for cooking and heating in rural areas of developing countries, such as China. ${ }^{26}$ The combustion products of these solid fuels include carbon monoxide, nitrogen dioxide, particulates and polycyclic hydrocarbons. Some coal is very high in sulfur and may contain toxic metals such as lead and chromium. Use of coal is associated with an increased risk of lung cancer (OR 2.65, 95\% CI 1.6-4.1) and childhood asthma (OR 2.3, 95\% CI $1.5-3.5) .^{26}$

\section{Carbon monoxide}

Indoor sources of carbon monoxide include vehicle exhaust from attached garages, gas stoves, furnaces, woodstoves, fireplaces and cigarettes. In California between 1979 and 1988, there were 270 deaths caused by accidental carbon monoxide poisoning from nonvehicular sources. ${ }^{27}$ Liu and colleagues ${ }^{28}$ reported that deaths were more common in winter and among men, black people and the elderly. Unvented combustion 
heaters and charcoal fuel were common sources of carbon monoxide. ${ }^{28}$ A 2005 report to the California legislature suggested that there are thousands of symptomatic but nonfatal cases each year in California. Symptoms of carbon monoxide poisoning, such as headache, nausea and fatigue, may be mistaken for the flu. ${ }^{27}$

\section{Nitrogen dioxide}

Nitrogen dioxide is an airway irritant that is emitted mainly during the combustion of fossil fuels. The indoor sources of nitrogen dioxide include combustion appliances such as gas or oil furnaces and stoves. ${ }^{29}$ Nitrogen dioxide may move from the outdoors to indoors; however, if from an outdoor source, it will be at a lower concentration in the home than if it were from an indoor source. Whether chronic exposure to low concentrations of nitrogen dioxide from indoor sources increases the risk of respiratory illnesses is unclear. In a cohort study that included over 1500 children aged 7-11 years at enrolment, long-term exposure to indoor nitrogen dioxide at concentrations greater than $38 \mu \mathrm{g} / \mathrm{m}^{3}$ was associated with a significantly increased risk of respiratory symptoms. ${ }^{30}$ However, 2 cohort studies that followed 1205 infants for 18 months after birth ${ }^{31}$ and 1611 infants for 12 months after birth ${ }^{32}$ did not find an effect of indoor nitrogen dioxide on the incidence of lower respiratory illness. Reasons for these conflicting findings are unknown, but perhaps older children are more susceptible than younger children to nitrogen dioxide. Older children are more likely to exhibit atopy and asthma, which may modify the response to nitrogen dioxide. This is shown by the observation that short-term inhalation of high concentrations of nitrogen dioxide increases bronchial responsiveness to inhaled allergens in sensitized asthmatics. ${ }^{33}$

\section{Off-gassing emissions}

Off-gassing emissions (gases released from indoor materials) include formaldehyde and volatile organic compounds (e.g., aliphatic and aromatic hydrocarbons) released from materials such as wood-based products, paints, floor finishes, glues, consumer products and freshly dry-cleaned clothing. Emissions are highest from new materials and recently applied paints and finishes. These products decay over time, explaining why concentrations of formaldehyde and volatile organic compounds are usually higher in newer homes than in older homes. ${ }^{34}$

\section{Formaldehyde}

At room temperature, formaldehyde is a gas. It is also available in an aqueous solution as formalin. It is an airway irritant and a possible carcinogen. In indoor environments, formaldehyde is mainly produced by off-gassing from wood-based products assembled using urea-formaldehyde resins (plywood, particle board, medium-density fibreboard). Other sources include cigarette smoke, certain paints, varnishes and floor finishes. ${ }^{35}$

A study of 96 homes in Québec City, Quebec, between January and April 2005 reported formaldehyde concentrations between 9.6 to $90.0 \mu \mathrm{g} / \mathrm{m}^{3}$ (mean $29.5 \mu \mathrm{g} / \mathrm{m}^{3}$ ). ${ }^{36}$ Greater concentrations of formaldehyde were associated with lower fresh air exchange and with painting, varnishing and acquiring new wooden or melamine furniture in the previous 12 months. ${ }^{36}$ Levels of formaldehyde in mobile homes, which generally have a high proportion of pressed wood products that contain urea-formaldehyde resin, tend to be even higher than the concentrations in homes with urea-formaldehyde foam insulation. ${ }^{37}$ Formaldehyde concentrations in homes are inversely correlated with the air change rate. ${ }^{36}$

Acute effects such as eye, nose and throat irritation have been observed following controlled exposures to concentrations of at least $1230 \mu \mathrm{g} / \mathrm{m}^{3}{ }^{38}$ However, in people with asthma and allergic sensitization to the dust mite Dermatophagoides pteronyssinus, inhalation of $100 \mu / \mathrm{m}^{3}$ formaldehyde for 30 minutes caused a significant increase in bronchial responsiveness to the mite. ${ }^{39}$ Associations between residential or school exposure to formaldehyde and respiratory symptoms has been reported in observational epidemiologic studies. ${ }^{40,41}$ In a study that included 298 children and 613 adults in Tucson, Arizona, Kryzanowski and colleagues ${ }^{40}$ reported that physician-diagnosed asthma and bronchitis, but not respiratory symptoms, were associated with increasing concentrations of formaldehyde. A $22 \%$ decrease in peak flow was estimated to occur for each 60 part per billion increase in home formaldehyde concentrations. ${ }^{40}$ Formaldehyde was declared a toxic substance by the 1999 Canadian Environmental Protection Act.?

\section{Volatile organic compounds}

The World Health Organization defines an organic compound as volatile if it has a melting point below room temperature and a boiling point between $50-100{ }^{\circ} \mathrm{C}$ and $240-260{ }^{\circ} \mathrm{C} .{ }^{42}$ The United States Environmental Protection Agency has a regulatory definition: a volatile organic compound is a carbon-containing compound that participates in atmospheric photochemical reactions. ${ }^{42}$

Cigarette smoke, recently dry-cleaned clothes and room deodorizers are major sources of volatile organic compounds. ${ }^{43}$ Wallace reported that exhaled benzene was 10 times higher for smokers than nonsmokers. ${ }^{44}$ Gasoline vapours have been found in homes with attached garages. ${ }^{5}$ Age of building materials is also an important determinant of the rate of offgassing. Exposure is much higher from wet paint and new carpets compared with dry paint and old carpets. ${ }^{45-47}$ The type and quantity of volatile organic compounds in the material, the surface area of the material and the depth of the volatile organic compounds within the material also affects exposure. ${ }^{48}$ In contrast, ventilation and air conditioning tend to reduce indoor volatile organic compounds. ${ }^{49}$ In general, indoor concentrations are higher than outdoor concentrations, and concentrations in winter are greater than in summer. ${ }^{50}$

Small clinically controlled studies have demonstrated bronchoconstriction from insecticides that contain pyrethrin and perfumes. ${ }^{51,52}$ In a study that included 88 adults, $50 \%$ of whom had asthma symptoms, Norback and colleagues ${ }^{53}$ found that respiratory symptoms were related to residential formaldehyde and volatile organic concentrations. Bronchial reactivity was related to limonene, a volatile terpene found in citrus fruits and often added to cleaning products. Wieslander and colleagues sampled 562 people in Uppsala, Sweden, in 1990 and found that asthma symptoms and bronchial hyper- 
reactivity were associated with both wood and kitchen painting in the previous 12 months. ${ }^{54}$ They report that total volatile organic compounds were $100 \mathrm{mg} / \mathrm{m}^{3}$ higher in homes that had been recently painted. ${ }^{54}$

The use of aerosol cleaning products has been associated with an increased incidence of asthma symptoms over an average follow-up period of 9 years. Among 3503 people in 10 European countries who used aerosolized products for glass cleaning, air freshening and furniture polishing, the relative risk was 1.49 (95\% CI 1.12-1.99) for asthma symptoms or medication use and 1.39 (95\% CI 1.06-1.80) for wheeze. There was a dose-response relation between the weekly frequency of using cleaning sprays and relative risk of asthma. Airways responsiveness, measured by methacholine bronchial challenge, was not associated with cleaning sprays. The use of nonaerosol products was not associated with asthma. ${ }^{55}$

\section{Plastic compounds}

Jaakkola and colleagues performed an age-matched case-control study within the Oslo birth cohort that included 3754 children. ${ }^{56}$ The clinical diagnosis of bronchial obstruction was more common among children living in homes with polyvinyl chloride than in homes with wood flooring (OR $1.89,95 \%$ CI 1.1-3.1). Bronchial obstruction was also more common among children in homes with textile wallpaper than with painted walls (OR 1.6, 95\% CI 1.0-2.5). In a second case-control study by this group, which included a cohort of 2568 children born between 1984 and 1989 in Espoo, Finland ${ }^{57}$ the authors report that plastic wall materials were associated with increased risk of asthma (OR 1.5, 95\% CI 0.4-6.7). There was also increased risk of wheeze, cough and phlegm (OR 3.4, 2.4 and 2.8 respectively). One explanation is that one major component of polyvinyl chloride is the plasticizer di-(2-ethylhexyl) phthalate and its hydrolysis product mono-(2-ethylhexyl) phthalate, which, in rats, induces bronchial hyperreactivity. ${ }^{58}$ The Third National Health and Nutrition Examination Survey, which included 240 adults, reported that increased levels of monobutyl phthalate were associated with decreased pulmonary function in men but not women..$^{59}$ For a change from the 25 th to the 75 th percentile in monobutyl phthalate level among men, 1-second forced expiratory volume decreased by $112 \mathrm{~mL}$ (standard error $51, p=0.03) .^{59}$

\section{Carcinogens}

\section{Radon}

The US Environmental Protection Agency estimates that residential radon causes about 21000 deaths because of lung cancer annually in the United States. ${ }^{60}$ Lung cancer typically develops 5-25 years after exposure. Radon, a radioactive gas, comes from the natural decay of uranium in soil. It enters the home through cracks and holes in the foundation and accumulates. Well water and building materials are not common sources. The average outdoor level of radon is about $0.4 \mathrm{pCi} / \mathrm{L}$ or $37 \mathrm{~Bq} / \mathrm{m}^{3}$. A study by the US Environmental Protection Agency that included homes in 50 states reported a mean indoor air radon concentration of $46 \mathrm{~Bq} / \mathrm{m}^{3}$, ranging be- tween $54 \mathrm{~Bq} / \mathrm{m}^{3}$ in single-family homes to $24 \mathrm{~Bq} / \mathrm{m}^{3}$ in multifamily homes. ${ }^{61}$ The level of radon on the first floor of a home may be less than half of the level in the basement. ${ }^{62}$

A Canadian survey performed between 1977 and 1980 that included 14000 homes reported a range of mean radon levels from $5.2 \mathrm{~Bq} / \mathrm{m}^{3}$ to $57 \mathrm{~Bq} / \mathrm{m}^{3}$. Of the included homes, 1 in 1000 homes had a radon level in excess of $800 \mathrm{~Bq} / \mathrm{m}^{3} .^{37}$ Based on a meta-analysis of 7 case-control studies in North America, the odds of developing lung cancer increased with residential radon exposure. The estimated OR for lung cancer 5-30 years after exposure was 1.11 (95\% CI 1.00-1.28) at $100 \mathrm{~Bq} / \mathrm{m}^{3}$. These results were not influenced by sex, education, or smoking. ${ }^{63}$ The upper radon exposure limit in the guidelines published by Health Canada is $200 \mathrm{~Bq} / \mathrm{m}^{3}$

\section{Asbestos}

Occupational exposure to asbestos causes lung cancer, mesothelioma and lung fibrosis. ${ }^{64}$ Asbestos is a fibrous mineral found in rock formations that has been widely used in home construction materials, such as floor and ceiling tiles, insulating board and pipe covers. A 2004 Canadian provincial government report stated that Canadian homes built over 20 years ago may have asbestos in the coverings of furnaces, ducts, pipes and flooring. ${ }^{65}$ Health Canada reports that if the asbestos fibres are enclosed or tightly bound in a compound, there is no significant health risk. ${ }^{66}$ If the asbestos material is more than slightly damaged or fragmented, or if home renovations that might disturb the material are planned, a professional should perform the repairs or renovations. Homeowners who are planning to remodel their homes should first find out whether asbestos-containing materials are present. ${ }^{67}$

\section{The health professional's role}

\section{When to suspect poor indoor air quality}

Allergic diseases such as rhinitis and asthma may be exacerbated by indoor allergens and irritants. Otitis media and respiratory infections are more frequent among children exposed to environmental tobacco smoke. Headaches may be a sign of carbon monoxide poisoning.

\section{How to screen for potential exposures}

Obtaining a short patient history is an important first step. Ask about the presence of furry or feathered pets; if there is a smoker in the home; if there is visible water damage, mould growth or mouldy smells; what heating sources are used; if there has been furnace maintenance; whether the patient or someone else in the home uses scented products; and which hobbies the patient participates in. Carpets, drapes and soft furnishings are reservoirs for fungi, dust mites, endotoxins, and pet and pest allergens. Generally, it is not possible to accurately predict the presence of elevated radon concentrations.

\section{When to suggest a home inspection}

If there is a suspicion of water leakage or mould growth, a building inspector could be called to examine the home. Air sampling is not generally recommended for fungi. A heating contractor should regularly inspect the furnace and check for 
gas leaks and carbon monoxide even in the absence of a suspected problem. Commercial companies can address concerns about radon and asbestos and provide remediation if necessary.

\section{Improving indoor air quality}

\section{Allergens}

If furry and feathered pets cannot be kept outside, they should be restricted to less inhabited parts of the home. After removal of a cat from the home, allergen levels fall over the next several months. ${ }^{68}$ Washing cats and dogs reduces allergen levels for a few days. ${ }^{69}$ If carpets, drapes and soft furnishings cannot be removed, frequent vacuuming with a HEPA (high-efficiency particulate air) filter or a central vacuum is recommended. Washing bedding materials in warm water can remove allergens. In a review of measures that can be taken to avoid allergens, Eggleston reported that completely encasing the mattress and pillows with coverings that are made of allergen-impermeable materials reduced allergen concentrations by about $89 \% .^{70}$ Although allergen concentrations can be effectively reduced, the size of the resulting health benefits are unknown. ${ }^{31-33}$ At this time, avoiding allergens is recommended for people with allergies.

\section{Chemical contaminants}

Trichloroethylenes can be reduced several-fold by not bringing recently dry-cleaned clothes into the house for a few days. Room deodorizers, perfumes and strong chemicals can be avoided. Automobiles should not be left running in attached garages. Emissions from fuel containers, lawn mowers and other yard tools can be avoided by storing them in a location that is not attached to the home. Solid hardwood furniture and flooring generally have less volatile emissions than particleboard, medium-density fibreboard, plywood and oriented strand board. Increasing home ventilation can effectively reduce the concentrations of volatile organic compounds.

\section{Combustion products}

Exposure to combustion products in the home should be avoided. Smoke alarms and carbon monoxide detectors provide early detection. Remediable sources of fine particulate and gaseous air pollution include cigarettes, candles, incense, and backdrafting or leaking woodstoves and fireplaces and furnaces. Living further away from heavy traffic is associated with reduced indoor exposure to combustion products. Indeed, nitric oxide falls to background levels by about $200 \mathrm{~m}$ from the roadway. ${ }^{71}$

Additional information about improving indoor air quality can be obtained from Health Canada (www.hc-sc.gc.ca/ewhsemt/air/in/index_e.html) and the Canada Mortgage and Housing Corporation (www.cmhc-schl.gc.ca/en/co/co _001.cfm).

\section{Conclusion}

Although allergen exposure causes symptoms in sensitized people, additional research about host and environmental characteristics is needed to determine if allergen exposure in- creases or decreases the risk of allergic disease in people who have not been previously sensitized. Fungus causes many diseases in clinical situations, and mould contamination of the home is associated with illness; however, causality has not been universally accepted. Cigarette smoke and high levels of carbon monoxide are accepted causes of illness, but the evidence for nitrogen dioxide is less certain. After smoking, inhalation of second-hand smoke and radon appear to be the most common cause of lung cancer.

Housing structure and function along with lifestyle decisions determine indoor air quality, which in turn influences health. Future research to improve our understanding of the health effects of indoor air quality has the potential to improve the health of our population.

This article has been peer reviewed.

Competing interests: None declared.

Contributors: Each of the authors contributed to the conception of the article and to the literature search and the synthesis and interpretation of the data. Each of the authors drafted and revised the manuscript and approved the final version to be published.

\section{REFERENCES}

1. Klepeis NE, Nelson WC, Ott WR, et al. The National Human Activity Pattern Survey (NHAPS): a resource for assessing exposure to environmental pollutants. $J$ Expo Anal Environ Epidemiol 2001;11:231-52.

2. Leech JA, Nelson WC, Burnett RT, et al. It's about time: a comparison of Canadian and American time-activity patterns. J Expos Anal Environ Epidemiol 2002;12:427-32.

3. Liu W, Zhang J, Korn LR, et al. Predicting personal exposure to airborne carbonyls using residential measurements and time/activity data. Atmos Environ 2007;41: 5280-8.

4. Kim D, Sass-Kortsak A, Pudham JT, et al. Sources of personal exposure to fine farticles in Toronto, Ontario, Canada. J Air Waste Manag Assoc 2005;55:1134-46.

5. Janssen NAH, Schwartz J, Zampbetto A, et al. Air conditioning and source-specific particles as modifiers of the effect of PM10 on hospital admissions for heart and lung disease. Environ Health Perspect 2002;110:43-9.

6. O'Neill MS, Jerrett M, Kawachi I, et al. Health, wealth, and air pollution: advancing theory and methods. Environ Heath Perspect 2003;111:1861-70.

7. Health Canada. Residential indoor air quality guideline: formaldehyde. Ottawa (ON): Health Canada; 2006. Available: www.hc-sc.gc.ca/ewh-semt/pubs/air /mould-moisissure e.html (accessed 2008 June 5).

8. Health Canada. Residential indoor air quality guideline: moulds. Ottawa (ON): Health Canada; 2007. Available: www.hc-sc.gc.ca/ewh-semt/pubs/air/mouldmoisissure e.html (accessed 2008 June 5).

9. Health Canada. Exposure guidelines for residential indoor air quality: Part A. substances with exposure guidelines - non-carcinogenic effects. Ottawa (ON): Health Canada; 2007. Available: www.hc-sc.gc.ca/ewh-semt/pubs/air/mouldmoisissure_e.html (accessed 2008 June 5).

10. Committee on the assessment of asthma and indoor air, Division of Health Promotion and Disease Prevention, Institute of Medicine. Clearing the air: asthma and indoor air exposure. Washington (DC): The National Academy Press; 2000. Available: www.nap.edu/openbook.php?isbn=0309064961 (accessed 2008 May 7).

11. Zeldin DC, Eggleston P, Chapman M, et al. How exposures to biologic influence the induction and incidence of asthma. Environ Health Perspect 2006;114:620-6.

12. Simpson A, Custovic A. Early pet exposure: Friend or foe? Curr Opin Allergy Clin Immunol 2003;3:7-14.

13. Lau S, Illi S, Sommerfield C, et al. Early exposure to house-dust mite and cat allergens and development of childhood asthma: a cohort study. Lancet 2000;356:1392-7.

14. Gehring U, Douwes J, Doekes G, et al. Beta $(1,3)$-glucan in house dust of German homes: housing characteristics, occupant behavior, and relations with endotoxins, allergens, and molds. Environ Health Perspect 2001;109:139-44.

15. Park J-H, Spiegelman DL, Burge HA, et al. Longitudinal study of dust and airborne endotoxin in the home. Environ Health Perspect 2000;108:1023-8.

16. Michel O, Kips J, Duchateau J, et al. Severity of asthma is related to endotoxin in house dust. Am J Respir Crit Care Med 1996;154:1641-6.

17. Park J-H, Gold DR, Spiegelman DL, et al. House dust endotoxin and wheeze in the first year of life. Am J Respir Crit Care Med 2001;163:322-8.

18. Dales R, Miller D, Ruest K, et al. Airborne endotoxin is associated with respiratory illness in the first 2 years of life. Environ Health Perspect 2006;114:610-4.

19. Von Mutius E, Braun-Fahrlander C, Schierl R, et al. Exposure to endotoxin or other bacterial components might protect against the development of atopy. Clin Exp Allergy 2000;30:1230-4. 
20. Reed CE, Milton DK. Endotoxin-stimulated innate immunity: a contributing factor for asthma. J Allergy Clin Immunol 2001;108:157-66.

21. Von Ehrenstein OS, Von Mutius E, Illi S, et al. Reduced risk of hay fever and asthma among children of farmers. Clin Exp Allergy 2000;30:187-93.

22. Lawton MD, Dales RE, White J. The influence of house characteristics in a Canadian community on microbiological contamination. Indoor Air 1998;8:11.

23. Fisk WJ, Lei-Gomez Q, Mendell MJ. Meta-analyses of the associations of respiratory health effects with dampness and mold in homes. Indoor Air 2007;17:284-96.

24. Committee on Damp Indoor Spaces and Health, Board of Health Promotion and Disease Prevention, Institute of Medicine. Damp indoor spaces and health. Washington (DC): The National Academic Press; 2004. Available: www.nap.edu/openbook .php?record_id=11011\&page $=17$ (accessed 2008 May 7)

25. United States Department of Health and Human Services. The Health consequences of involuntary exposure to tobacco smoke: a report of the Surgeon General. Atlanta (GA):The Department; 2006. Available: www.surgeongeneral.gov /library/secondhandsmoke/ (accessed 2008 May 7).

26. Zhang JJ, Smith KR. Household air pollution from coal and biomass fuels in China: Measurements, health impacts, and interventions. Environ Health Perspect 2007:115:848-55.

27. California Environmental Protection Agency. Shimer D, Phillips TJ, Jenkins PL. Report to the California Legislature: indoor air pollution in California. Sacramento (CA): The Agency; 2005. p.1-363. Available: www.calepa.ca/gov/publications/Reports/Mandated/2005/IndoorAir.pdf (accessed 2008 May 7).

28. Liu KS, Paz MK, Flessel P, et al. Unintentional carbon monoxide deaths in California from residential and other nonvehicular sources. Arch Environ Health 2000;55:375-81.

29. Burr ML: Combustion products. In: Spengler JD, Samet JM, McCarthy JF, editors. Indoor air quality handbook. New York: McGraw-Hill; 2000. p29.10-29.11.

30. Neas LM, Dockery DW, Ware JH, et al. Association of indoor nitrogen dioxide with respiratory symptoms and pulmonary function in children. Am J Epidemio 1991;134:204-19.

31. Samet JM, Lambert WE, Skipper BJ, et al. Nitrogen dioxide and respiratory illnesses in infants. Am Rev Respir Dis 1993;148:1258-65.

32. Sunyer J, Puig C, Torrent M, et al. Nitrogen dioxide is not associated with respiratory infection during the first year of life. Int J Epidemiol 2004;33:116-20

33. Jenkins HS, Devalia JL, Mister RL, et al. The effect of exposure to ozone and nitrogen dioxide on the airway response of atopic asthmatics to inhaled allergen: dose- and time-dependent effects. Am J Respir Crit Care Med 1999;160:33-9.

34. Park JS, Ikeda K. Variations of formaldehyde and VOC levels during 3 years in new and older homes. Indoor Air 2006;16:129-35.

35. International Program on Chemical Safety. Environmental Health Criteria 89 Formaldehyde. 2nd ed. Geneva: The World Health Organization; 1989. Available: www.inchem.org/documents/ehc/ehc/ehc89.htm (accessed 2008 May 7).

36. Gilbert NL, Gauvin D, Guay M, et al. Housing characteristics and indoor concentrations of nitrogen dioxide and formaldehyde in Québec City, Canada. Environ Res 2006;102:1-8

37. Health Canada. Exposure guidelines for residential indoor air quality. Ottawa (ON): Health Canada; 2006. Available: www.hc-sc.gc.ca/ewh-semt/pubs/ai /exposure-exposition/index e.html (accessed 2008 May 7).

38. Kulle TJ. Acute odor and irritation response in healthy nonsmokers with formaldehyde exposure. Toxicol Ind Health 1993;5:323-32.

39. Casset A, Marchand C, Purohit A, et al. Inhaled formaldehyde exposure: effect on bronchial response to mite allergen in sensitized asthma patients. Allergy 2006;61: 1344-50.

40. Krzyzanowski M, Quackenboss JJ, Lebowitz MD. Chronic respiratory effects of indoor formaldehyde exposure. Environ Res 1990;52:117-25.

41. Rumchev KB, Spickett JT, Bulsara MK, et al. Domestic exposure of formaldehyde significantly increases the risk of asthma in young children. Eur Respir J 2002;20 403-8

42. Tucker WG. Volatile organic compounds. In: Spengler JD, Samet JM, McCarthy JF, editors. Indoor air quality handbook. New York (NY): McGraw-Hill; 2000. p 31.1-31.20.

43. Torén K, Hermansson BA. Incidence rate of adult-onset asthma in relation to age, sex, atopy and smoking: a Swedish population-based study of 15813 adults. Int J Tuberc Lung Dis 1999;3:192-7.

44. Wallace LA. Assessing human exposure to volatile organic compounds. In: Spengler JD, Samet JM, McCarthy JF, editors. Indoor air quality handbook. New York (NY): McGraw-Hill; 2000. p. 33.1-33.35.

45. Hodgson AT, Rudd AF, Beal D, et al. Volatile organic compounds concentrations and emission rates in new manufactured and site-built houses. Indoor Air 2000;10:178-92.

46. Hodgson AT, Wooley JD, Daisey JM. Emissions of volatile organic compounds from new carpets measured in a large-scale environmental chamber. Air Waste 1993;43:316-24.

47. Sparks LE, Guo Z, Chang JC. Volatile organic compound emissions from latex paint - Part 2. Test house studies and indoor air quality (IAQ) modeling. Indoor Air 1999;9:18-25.

48. Meininghaus R, Kirchner S, Maupetit F, et al. Gravimetric studies on VOC adsorption by indoor materials under near-ambient conditions. Indoor Built Environ 2000;9:277-283.

49. Clobes AL, Ananth GP, Hood AL, et al. Human activities as sources of volatile organic compounds in residential environments. Ann N Y Acad Sci 1992;641:79-86.

50. Wallace L, Nelson W, Ziegenfus R, et al. The Los Angeles Team Study: personal exposures, indoor-outdoor air concentrations, and breath concentrations of 25 volatile organic compounds. J Expo Anal Environ Epidemiol 1991;1:157-92.

51. Salome CM, Marks GB, Savides P, et al. The effect of insecticide aerosols on lung function, airway responsiveness and symptoms in asthmatic subjects. Eur Respir J 2000;16:38-43.

52. Baur X, Schneider EM, Wieners D, et al. Occupational asthma to perfume. Allergy 1999;54:1334-5.

53. Norbäck D, Björnsson E, Janson C, et al. Asthmatic symptoms and volatile organic compounds, formaldehyde, and carbon dioxide in dwellings. Occup Environ Med 1995;52:388-95

54. Wieslander G, Norbäck D, Björnsson E, et al. Asthma and the indoor environment: the significance of emission of formaldehyde and volatile organic compounds from newly painted indoor surfaces. Int Arch Occup Environ Health 1997;69:115-24.

55. Zock JP, Plana E, Jarvis D, et al. The use of household cleaning sprays and adult asthma: an international longitudinal study. Am J Respir Crit Care Med 2007; 176:735-41.

56. Jaakkola JJ, Oie L, Nafstad P, et al. Interior surface materials in the home and the development of bronchial obstruction in young children in Oslo, Norway. Am J Public Health 1999;89:188-92.

57. Jaakkola JJ, Verkasalo PK, Jaakkola N. Plastic wall materials in the home and respiratory health in young children. Am J Public Health 2000;90:797-9.

58. Nordman H, Keskinen H, Tuppurainen M. Formaldehyde asthma: Rare or overlooked? J Allergy Clin Immunol 1985;75:91-9.

59. Hoppin JA, Ulmer R, London SJ. Phthalate exposure and pulmonary function. Environ Health Perspect 2004;112:571-4.

60. United States Environmental Protection Agency (EPA). EPA assessment of risks from radon in homes. Washington (DC): Office of Indoor Radiation and Air US EPAgency; 2003. Available: www.epa.gov/radon001/pdfs/402-r-03-003.pdf (accessed 2008 May 7).

61. Marcinowski F, Lucas RM, Yeager WM. National and regional distributions of airborne radon concentrations in U.S. homes. Health Phys 1994;66:699-706

62. Committee on Health Risks of Exposure to Radon. Health effects of exposure to radon. Washington (DC): National Academy Press; 1999. Available: http://books.nap.edu/openbook.php?isbn=0309056454 (accessed 2008 May 7).

63. Krewski D, Lubin JH, Zielenski JM, et al. Residential radon and risk of lung cancer: a combined analysis of 7 North American case-control studies. Epidemiology 2005; 16:137-45.

64. Ohar J, Sterling DA, Bleeker E, et al. Changing patterns in asbestos-induced lung disease. Chest 2004; 125:744-53.

65. British Columbia Health Files. Asbestos: When should I worry? Victoria (BC): British Columbia Ministry of Health; 2004 Available: www.bchealthguide .org/healthfiles/hfile32.stm (accessed 2008 May 7).

66. Health Canada. Health risks of asbestos. Ottawa (ON): Health Canada; 2001 Available: www.hc-sc.gc.ca/iyh-vsv/environ/asbestos-amiante_e.html (accessed 2008 May 7).

67. US Environmental Protection Agency. Asbestos in Your Home. Washington (DC): The Agency; 2007 Available: www.epa.gov/asbestos/pubs/ashome.html (accessed 2008 May 7).

68. Wood RA, Chapman MD, Adkinson NF, et al. The effect of cat removal on allergen content in household-dust samples. J Allergy Clin Immunol 1989;83:730-4.

69. Avner DB, Perzanowski MS, Platts-Mills TAE, et al. Evaluation of different techniques for washing cats: quantitation of allergen removed from the cat and effect on airborne Fel d I. J Allergy Clin Immunol 1997;100:307-12.

70. Eggleston PA. Improving indoor environments: Reducing allergen exposures. $J \mathrm{Al}$ lergy Clin Immunol 2005;116:122-6.

71. Gilbert NL, Woodhouse S, Stieb DM, et al. Ambient nitrogen dioxide and distance from a major highway. Sci Total Environ 2003;312:43-6.

Correspondence to: Dr. Robert Dales, Air Quality Health Effects Research Section, Biostatistics and Epidemiology Division, Health Canada, 3rd Floor, PL 4903B or 4903C, 269 Laurier Ave. W, Ottawa ON K1A 0K9; R_Dales@hc-sc.gc.ca 